\title{
Visualization and quantification of mimetic musculature via DiceCT
} \author{
Adam Hartstone-Rose ${ }^{1}$ \\ ${ }^{1}$ Department of Biological Sciences, North Carolina State University, Raleigh, North Carolina, United States \\ 2 Department of Anthropology, University of Florida, Gainesville, Florida, United States \\ 3 Department of Physical Therapy, Duquesne University, Pittsburgh, Pennsylvania, United States \\ 4 Department of Anthropology, University of Pittsburgh, Pittsburgh, Pennsylvania, United States \\ Corresponding Author: Edwin Dickinson \\ Email address: edwin_dickinson@ncsu.edu
}

Edwin Dickinson ${ }^{\text {Corresp., }}{ }^{1}$, Emily Atkinson ${ }^{1}$, Antonio Meza ${ }^{1}$, Shruti Kolli ${ }^{1}$, Ashley R Deutsch ${ }^{2}$, Anne M Burrows ${ }^{3,4}$,

The muscles of facial expression are of significant interest to studies of communicative behaviors. However, due to their small size and high integration with other facial tissues, the current literature is largely restricted to descriptions of the presence or absence of specific muscles. Using diffusible iodine-based contrast-enhanced computed tomography (DiceCT) to stain and digitally image the mimetic mask of Eulemur flavifrons (the blueeyed black lemur), we demonstrate - for the first time - the ability to visualize these muscles in three-dimensional space and to measure their relative volumes. Comparing these data to earlier accounts of mimetic organization with the face of lemuroidea, we demonstrate several novel configurations within this taxon, particularly in the superior auriculolabialis and the posterior auricularis. We conclude that DiceCT facilitates the study these muscles in closer detail than has been previously possible, and offers significant potential for future studies of this anatomy. 
1 Visualization and quantification of mimetic musculature via DiceCT

2 Authors: Edwin Dickinson ${ }^{1}$, Emily Atkinson ${ }^{1}$, Antonio Meza ${ }^{1}$, Shruti Kolli ${ }^{1}$, Ashley R Deutsch ${ }^{2}$,

3 Anne M Burrows ${ }^{3,4}$, Adam Hartstone-Rose ${ }^{1}$

4 Affiliations: ${ }^{1}$ Department of Biological Sciences, North Carolina State University, Raleigh, NC.

$5 \quad{ }^{2}$ Department of Anthropology, University of Florida, Gainesville, Florida.

$6 \quad{ }^{3}$ Department of Physical Therapy, Duquesne University.

$7 \quad{ }^{4}$ Department of Anthropology, University of Pittsburgh.

8 Corresponding Author: Edwin Dickinson. Email: edwin_dickinson@ncsu.edu

9 Address: Department of Biological Sciences, Campus Box 7614, 3546 Thomas Hall, Raleigh

10 NC, 27695.

\section{Abstract}

12 The muscles of facial expression are of significant interest to studies of communicative

13 behaviors. However, due to their small size and high integration with other facial tissues, the

14 current literature is largely restricted to descriptions of the presence or absence of specific

15 muscles. Using diffusible iodine-based contrast-enhanced computed tomography (DiceCT) to

16 stain and digitally image the mimetic mask of Eulemur flavifrons (the blue-eyed black lemur),

17 we demonstrate - for the first time - the ability to visualize these muscles in three-dimensional

18 space and to measure their relative volumes. Comparing these data to earlier accounts of mimetic

19 organization with the face of lemuroidea, we demonstrate several novel configurations within

20 this taxon, particularly in the superior auriculolabialis and the posterior auricularis. We conclude

21 that DiceCT facilitates the study these muscles in closer detail than has been previously possible,

22 and offers significant potential for future studies of this anatomy.

\section{Introduction}

24 Mimetic muscles - or the muscles of facial expression - are associated with social

25 communication in visually oriented species. They can be broadly classified into three separate 
26 groups based on their location and function (muscles surrounding the external ear; muscles of the 27 superciliary region/orbital region; and muscles of the mid-face/oral region), and all are intimately

28

29

30 31 32 association with the skin of the face. Additionally, the platysma - which originates postcranially - inserts around the mouth and cheeks and contributes to oral expression. Over the past century, numerous anatomical reports have sought to describe the gross anatomy of these muscles in primates (e.g., Murie and Mivart, 1869, Lightoller, 1925, Sullivan and Osgood, 1925, Lightoller, 1928, Huber, 1930, Lightoller, 1934, Shibata, 1959, Seiler, 1970, Swindler and Wood, 1973, Seiler, 1977, Pellet, 1979, Burrows and Smith, 2003, Burrows et al., 2006, Burrows 2008, Burrows et al., 2009, Diogo et al., 2009, Powell et al., 2018). More recently still, analyses of variation in mimetic muscle organization between dogs and wolves have shone light on intriguing differences in communication resulting from the process of domestication (Kaminski et al., 2019). However, to date, all studies of these muscles have been limited to qualitative descriptions regarding the presence, absence, and orientation of particular muscles. This likely reflects a confluence of factors, including their small size, superficial positioning within the face, and intimate integration with the skin - each of which render the mimetic musculature difficult to individually excise and analyze using traditional gross dissection techniques. Consequently, alternative techniques for the analyses of muscle volume and configuration are necessary to more comprehensively evaluate these muscles.

In recent years, new imaging modalities such as diffusible iodine-based contrast-enhanced computed tomography (DiceCT) have emerged as a means of visualizing and quantifying myological data in situ (Gignac et al., 2016). Typically, X-ray computed tomography is reserved for the visualization of mineralized materials such as bone; however, pretreatment of specimens with a chemical stain (such as phosphomolybdic acid or, as in DiceCT, iodine) capable of binding to carbohydrates in soft tissues ( $\mathrm{Li}$ et al., 2015) makes it possible to apply this technique to the analysis of myology. Using this technique, muscle volumes can be visualized within CT stacks, segmented, and digitally reconstructed - permitting the three-dimensional visualization of their form, and quantification of morphometric data such as surface area and volume (e.g., Cox and Jeffery, 2011, Jeffery et al., 2011, Baverstock et al., 2013, Holliday et al., 2013, Cox and Faulkes, 2014, Gignac and Kley, 2014). Indeed, recent advances have even permitted the reconstruction of individual fascicles within whole muscle volumes (Kupczik et al., 2015, Dickinson et al., 2018, Dickinson et al., 2019a,b, Sullivan et al., 2019). 
57 As this methodology facilitates the visualization of subdermal tissues in situ, DiceCT

58 circumvents the obstacles that limit our ability to quantitatively assess the relative proportions of

59 the mimetic musculature. In so doing, it becomes possible to compare three-dimensional data on

60 the size and configuration of these muscles across species, potentially unlocking new insights

61 into mimetic diversity across primates within the context of communicative behavioral

62 repertoires. Within this pilot study we demonstrate the potential of this technique for

63 quantification of these under-studied muscles within a strepsirrhine taxon, the blue-eyed black

64 lemur (Eulemur flavifrons). As these muscles have been qualitatively described from several

65 closely-related species of lemur (e.g., Murie and Mivart, 1869, Lightoller, 1934, Burrows and

66 Smith, 2003), the use of this taxon will facilitate comparison of our observations to those of these

67 preceding studies.

\section{Materials \& Methods}

69

70

71

72

73

74

75

76

77

78 79

80

81

82

83

\section{Specimen Preparation}

Our specimen consisted of an adult male blue-eyed black lemur (Eulemur flavifrons) sourced from the Duke Lemur Center (DLC6655m), that died of natural causes prior to the acquisition of the specimen. The cranial length of the specimen was $91 \mathrm{~mm}$. Preparation of the specimen for scanning was conducting following the technique of 'reverse dissection' outlined by Burrows et al. (2019). The head was first disarticulated from the neck, and precise incisions were made in order to divide the face bilaterally. One half of the face was removed from its bony attachments, then exposed to the air in order to desiccate any remaining connective tissues. No visible muscle tissue was left on the head following removal of the facial mask.

8 The resulting face mask was fixed in $10 \%$ buffered formalin for 48 hours to preserve the tissue 9 during the staining procedure. The mask was then submerged in a $2.625 \% \mathrm{w} / \mathrm{v}$ solution of 80 Lugol's iodine $\left(\mathrm{I}_{2} \mathrm{KI}\right)$, with care taken to rest the specimen within a natural configuration, with 1 all muscles below the surface of the solution. After two weeks, the face masks were removed 82 from this solution and rinsed with distilled water. The mask was then wrapped in damp paper 83 towels and placed in a sealed plastic bag for 24 hours before scanning. 


\section{Scanning}

85 In preparation for scanning, the face mask was mounted onto floral foam (a low-density

86

87

88 89

90

91

92

93

94

95

96

97

98

99

100

101

102

103

104

105

106

107

108

109

110 material) and secured with wooden toothpicks to eliminate wrinkles and to limit movement of the mask during scanning. Using a Nikon XTH 225 ST micro-CT system housed at the Shared Materials Instrumentation Facility (SMIF) at Duke University, the mounted face mask was scanned at $130 \mathrm{kV}$ and $171 \mathrm{~mA}$ with a $0.125 \mathrm{~mm}$ copper filter. The resultant images were reconstructed in 16bit, resulting in an isometric voxel size of $0.0509 \mathrm{~mm}$ and scan dimensions of $2553 \times 1602 \times 1337$ slices.

\section{Segmentation}

From the reconstructed image stack (2D slice in Fig. 1; data in Supp. 1), we identified and segmented fifteen mimetic muscles: the frontalis, occipitalis, platysma, orbicularis oris, orbicularis oculi, anterior auricularis, superior and inferior posterior auricularis, superior and inferior auriculolabialis, levator labii, mentalis, mandibuloauricularis, tragicus, and depressor helicis, using Amira 6.3 (Thermo Fisher Scientific). Due to the thin nature of each muscle portion, muscles were manually segmented in multiple anatomical planes to aid interpretation and ensure that no muscle tissue was disregarded. Three-dimensional volumes (constrained smoothing, intensity $=3$ ) were produced of each labeled muscle, from which the volume of each muscle was calculated (Table 1).

\section{Results}

Contrast-enhanced computed tomography and digital reconstruction of the facial mask of $E$. flavifrons permitted both three-dimensional visualization and volumetric quantification of the mimetic musculature within this specimen. In total, 14 muscle volumes were quantified, totaling $1086.21 \mathrm{~mm}^{3}$. A visual representation of these muscles in E. flavifrons, including a superimposition of these muscles relative to the skull, is presented in Figure 2. Volumes were measured for all muscles barring the platysma, as the infero-caudal portion of this muscle originating from the clavicle was absent from our face mask, such that any volume would be incomplete. A full summary of the mimetic muscles and their volumes is presented in Table 1. 
111 In addition to this volumetric data, the three-dimensional visualization of these muscles also

112 enables us to compare the configuration and organization of these muscles to previous qualitative

113 accounts of the mimetic muscles within other species of Lemuroidea (Table 2). Several muscles

114 closely accorded with earlier descriptions; the orbicularis oris, tragicus, anterior auricularis,

115 platysma, and frontalis all display similar patterns of organization to existing descriptions of

116 these muscles within Lemuroidea and Lorisoidea. Similarly, fibers from the inferior

117 auriculolabialis arise from the superior border of platysma, following descriptions of this muscle

118 within Otolemur by Burrows and Smith (2003) but contrasting to descriptions by Lightoller

119 (1934). The latter noted a small gap between these muscles in Eulemur macaco and a hybrid

120 black lemur.

121 A number of remaining muscles - most prominently the orbicularis oculi, superior

122 auriculolabialis, and posterior auricularis - demonstrated significant variation from earlier

123 descriptions of the mimetic muscles in adult strepsirrhines. Burrows and Smith (2003) report

124 integration between fibers of the orbicularis oculi and superior auriculolabialis within Otolemur,

125 with the o. oculi giving rise to the superior auriculolabialis. Within E. flavifrons, however, no

126 interdigitation between fibers of these two muscles was observed when examining the muscles in

127 digital space. We did, however, note significant integration between the superior auriculolabialis

128 and posterior-inferior fibers of the frontalis muscle. Anterior fibers of the superior

129 auriculolabialis both integrate with fibers from the posterior frontalis and, in some regions,

130 overlap such that these fibers sit immediately deep to overlying fascicles from the frontalis. This

131 integration is not reported within Otolemur (Burrows and Smith, 2003) nor Eulemur macaco and

132 the hybrid black lemur described by Lightoller (1934).

133 Finally, we note variation in the configuration of the posterior auricularis from descriptions of

134 this muscle by both (Lightoller, 1934) and Burrows and Smith (2003). Within Eulemur macaco

135 and the hybrid black lemur, this muscle is described as comprising three bellies, while Burrows

136 and Smith (2003) describes two distinct bellies of equal size in Otolemur. The organization of

137 this muscle in E. flavifrons is similar to that of Otolemur in comprising two bellies; however,

138 within our specimen the superior belly possesses a volume almost twice as large as the inferior

139 belly (14.96 vs. $\left.8.17 \mathrm{~mm}^{3}\right)$.

140 Discussion

141 Digital reconstruction of the facial mask of E. flavifrons makes it possible to report, for the first 
142 time, quantitative data on the size of these highly-integrated muscles (Table 1). Our

143 visualizations also enable us to compare the configuration and organization of these muscles to

144 previous qualitative accounts of the mimetic muscles within other species of Lemuroidea. As

145 described above, several muscles closely accorded with earlier descriptions. Additionally, a

146 minor deviation from one earlier description was observed within the inferior auriculolabialis.

147 A number of remaining muscles demonstrated more significant variation from earlier

148 descriptions. Burrows and Smith (2003) report integration between fibers of the orbicularis oculi

149 and superior auriculolabialis within Otolemur, with the O. oculi giving rise to the superior

150 auriculolabialis. Within E. flavifrons, however, no interdigitation between fibers of these two

151 muscles was observed when examining the muscles in digital space. We did, however, note

152 significant integration between the superior auriculolabialis and posterior-inferior fibers of the

153 frontalis muscle. Anterior fibers of the superior auriculolabialis both integrate with fibers from

154 the posterior frontalis and, in some regions, overlap such that these fibers sit immediately deep to

155 overlying fascicles from the frontalis. This integration is not reported within Otolemur (Burrows

156 and Smith, 2003) nor Eulemur macaco and the hybrid black lemur described by Lightoller

157 (1934). Finally, we note variation in the configuration of the posterior auricularis from

158 descriptions of this muscle by both Lightoller (1934) and Burrows and Smith (2003). Within

159 Eulemur macaco and the hybrid black lemur, this muscle is described as comprising three

160 bellies, while Burrows and Smith (2003) describes two distinct bellies of equal size in Otolemur.

161 The organization of this muscle in E. flavifrons is similar to that of Otolemur in comprising two

162 bellies; however, within our specimen the superior belly possesses a volume almost twice as

163 large as the inferior belly (14.96 vs. $\left.8.17 \mathrm{~mm}^{3}\right)$.

164 By combining the reverse-dissection technique with a high-resolution DiceCT protocol, we 165 successfully establish herein a novel method for the three-dimensional visualization and 166 quantification of the mimetic musculature. This study provides further evidence of the value of 167 contrast-enhanced tomographic techniques in permitting the quantification of skeletal muscle 168 volumes, following earlier studies (e.g., Cox and Jeffery, 2011, Baverstock et al., 2013, 169 Lautenschlager, 2013, Cox and Faulkes, 2014, Dickinson et al., 2018). Indeed, this protocol 170 enabled the quantification of muscles with volumes as small as $4-10 \mathrm{~mm}^{3}$. However, it should be 171 noted that not all portions of the face could be visually resolved; specifically, the nasal/rostral 
172 region presented small muscles which were highly integrated with connective tissues in an

173 inconsistent manner, such that anatomical boundaries between muscle bodies could not be

174 confidently discerned, and individual fascicles could typically not be resolved. It is therefore

175 possible that sub-region scanning of this anatomy at even higher $(<20 \mu \mathrm{m})$ resolutions may be

176 necessary to accurately quantify this musculature.

177 Though these initial results appear promising, several caveats to the present study should be

178 noted. Firstly, the inherent intra-specific variation in the organization of the mimetic musculature

179 (as demonstrated in humans; e.g., (Watanabe, 2016)) precludes confident interpretation of

180 evolutionary trends from single-specimen samples. Additionally, it is important to consider the

181 potential for volumetric modification of muscles during the preparation process. Indeed,

182 excision, the dessication of extraneous tissues, and staining could all potentially impact the final

183 volumes by inducing shrinkage of superficially exposed tissues. Therefore, while the current

184 study applies this protocol to an isolated facemask, future studies of mimetic muscle organization

185 may wish to explore the anatomy of these muscles in situ. Although this method would likely

186 necessitate a longer staining time, the mimetic muscles can be clearly seen in some DiceCT

187 specimens that have been prepared for analysis of other regions (e.g., the focal specimen from

188 Dickinson et al. 2019b). In situ quantification would also enable the visualization of mimetic

189 muscle tissues in direct association with the underlying morphology of the face, as well as

190 minimizing the potential for muscle deformation and shrinkage associated with the excision and

191 staining process. Though this effect appeared relatively minimal for the muscles analyzed herein,

192 the extreme borders of several muscles displayed a slight curvature interpreted to reflect an

193 unnatural curling of the muscle tissue into itself. In situ analyses in which surrounding tissues

194 can stabilize these muscles may therefore yield even more precise data on muscle organization

195 within the face. This would in turn allow, for the first time, the three-dimensional visualization of

196 mimetic muscles from their origins to their insertions.

\section{Conclusions}

198 The application of DiceCT permits both the visualization of the mimetic musculature in three-

199 dimensional space and, for the first time, the quantification of muscle volumes for these small

200 and highly-integrated tissues. These novel data further demonstrate the potential for contrast-

201 enhanced tomographic techniques in enhancing our anatomical understanding of small and 
202 obscured structures. Future studies may apply an adapted protocol to visualize these tissues in 203 situ within other taxa, and provide more spatial context for these muscles in relation to other 204 tissues of the face.

\section{Acknowledgements}

206 We would like to thank the Editor, two anonymous reviewers, and Philip Cox for their comments 207 during the review process, which have helped to clarify and improve this manuscript. We are 208 grateful to Justin Gladman for assistance with scanning, and the Duke Lemur Center for 209 providing the specimen. This work was performed in part at the Duke University Shared 210 Materials Instrumentation Facility (SMIF), a member of the North Carolina Research Triangle 211 Nanotechnology Network (RTNN). This is Duke Lemur Center Publication Number \#\#\#.

\section{References}

213 Baverstock H, Jeffery NS, Cobb SN (2013) The morphology of the mouse masticatory 214 musculature. Journal of Anatomy, 223, 46-60.

215 216

Burrows AM. 2008. The facial expression musculature in primates and its evolutionary significance. Bioessays 30(3):212-225.

Burrows AM, Omstead KM, Deutsch AR, Gladman JT, and Hartstone-Rose A. 2019. Reverse Dissection and DiceCT Reveal Otherwise Hidden Data in the Evolution of the Primate Face. JoVE 143:e58394.

Burrows AM, and Smith TD. 2003. Muscles of facial expression in Otolemur, with a comparison to Lemuroidea. The Anatomical Record 274:827-836.

Burrows AM, Waller BM, and Parr LA. 2009. Facial musculature in the rhesus macaque (Macaca mulatta): evolutionary and functional contexts with comparisons to chimpanzees and humans. Journal of Anatomy 215:320-334.

Burrows AM, Waller BM, Parr LA, and Bonar CJ. 2006. Muscles of facial expression in the chimpanzee (Pan troglodytes): descriptive, comparative and phylogenetic contexts. Journal of Anatomy 208:153-167.

Cox PG, Faulkes CG (2014) Digital dissection of the masticatory muscles of the naked mole-rat, Heterocephalus glaber (Mammalia, Rodentia). PeerJ, 2, e448.

Cox PG, Jeffery N (2011) Reviewing the morphology of the jaw-closing musculature in squirrels, rats, and guinea pigs with contrast-enhanced microCT. The Anatomical Record, 294, 915-928. 
233 Dickinson E, Basham C, Rana A, Hartstone-Rose A (2019a). Visualization and Quantification of

234

235

236

237

238

239

240

241

242

243

244

245

246

247

248

249

250

251

252

253

254

255

256

257

258

259

260

261

262

263

264

Digitally Dissected Muscle Fascicles in the Masticatory Muscles of Callithrix jacchus Using Nondestructive DiceCT. The Anatomical Record 302: 1891-1900.

Dickinson E, Kolli S, Schwenk A, Davis CE, Hartstone-Rose A (2019b). DiceCT Analysis of the Extreme Gouging Adaptations Within the Masticatory Apparatus of the Aye-Aye (Daubentonia madagascariensis)." The Anatomical Record (online in early view).

Dickinson E, Stark H, Kupczik K (2018) Non-destructive determination of muscle architectural variables through the use of DiceCT. The Anatomical Record, 301, 363 - 377.

Diogo R, Wood BA, Aziz MA, Burrows A (2009) On the origin, homologies and evolution of primate facial muscles, with a particular focus on hominoids and a suggested unifying nomenclature for the facial muscles of the Mammalia. Journal of Anatomy, 215, 300-319.

Gignac PM, Kley NJ (2014) Iodine-enhanced micro-CT imaging: Methodological refinements for the study of the soft-tissue anatomy of post-embryonic vertebrates. Journal of Experimental Zoology Part B, 322, 166-176.

Gignac PM, Kley NJ, Clarke JA, Colbert MW, Morhardt AC, Cerio D, Cost IN, Cox PG, Daza JD, Early CM, Echols MS, Henkelman RM, Herdina AN, Holliday CM, Li Z, Mahlow K, Merchant S, Mueller J, Orsbon CP, Paluh DJ, Thies ML, Tsai HP, Witmer LM (2016) Diffusible iodine-based contrast-enhanced computed tomography (diceCT): an emerging tool for rapid, high-resolution, 3-D imaging of metazoan soft tissues. Journal of Anatomy, 228, 889-909.

Holliday CM, Tsai HP, Skiljan RJ, George ID, Pathan S (2013) A 3D interactive model and atlas of the jaw musculature of Alligator mississippiensis. PLoS One, 8, e62806.

Huber E (1930) Evolution of facial musculature and cutaneous field of trigeminus. Part I. The Quarterly Review of Biology, 5, 133-188.

Jeffery NS, Stephenson RS, Gallagher JA, Jarvis JC, Cox PG (2011) Micro-computed tomography with iodine staining resolves the arrangement of muscle fibres. Journal of Biomechanics, 44, 189-192.

Kaminski J, Waller BM, Diogo R, Hartstone-Rose A, Burrows AM (2019) Evolution of facial muscle anatomy in dogs. Proceedings of the National Academy of Sciences, 201820653.

Kupczik K, Stark H, Mundry R, Neininger FT, Heidlauf T, Röhrle O (2015) Reconstruction of muscle fascicle architecture from iodine-enhanced microCT images: a combined texture mapping and streamline approach. Journal of Theoretical Biology, 382, 34-43.

Peer] reviewing PDF | (2019:12:44023:2:0:NEW 7 May 2020) 
265 266

267 268 269

270 271

272 273

274 275

276 277

278 279

280 281 282

Lautenschlager S (2013) Cranial myology and bite force performance of E rlikosaurus andrewsi: a novel approach for digital muscle reconstructions. Journal of Anatomy, 222, 260-272.

Li Z, Clarke JA, Ketcham RA, Colbert MW, Yan F (2015) An investigation of the efficacy and mechanism of contrast-enhanced X-ray computed tomography utilizing iodine for large specimens through experimental and simulation approaches. BMC physiology, 15, 5.

Lightoller G (1928) The facial muscles of three orang utans and two cercopithecidae. Journal of Anatomy, 63, 19.

Lightoller GHS (1925) Facial Muscles: The Modiolus and Muscles surrounding the Rima Oris with some remarks about the Panniculus Adiposus1. Journal of Anatomy, 60, 1.

Lightoller GS (1934) The Facial Musculature of some Lesser Primates and a Tupaia. A Comparative Study. Proceedings of the Zoological Society of London, 104, 259-309.

Murie J, Mivart G (1869) On the Anatomy of the Lemuroidea. The Transactions of the Zoological Society of London, 7, 1-113.

Pellet A (1979) The facial muscles of three African primates contrasted with those of Patio ursinus. South African Journal of Science, 75, 436.

Powell V, Esteve-Altava B, Molnar J, Villmoare B, Pettit A, Diogo R (2018) Primate modularity and evolution: first anatomical network analysis of primate head and neck musculoskeletal system. Scientific Reports, 8, 2341.

Ruge, G., Uber die Gesichtsmuskulatur der Halbaffen. Morph Jahrbuch, 1885. 11: p. 243-315.

Seiler R (1970) Differences in the facial musculature of the nasal and upper-lip region in catarrhine primates and man. Zeitschrift fuer Morphologie und Anthropologie, 62, 267275.

Seiler R (1977) Morphological and functional differentiation of muscles. Studies on the m.frontalis, auricularis superior and auricularis anterior of primates including man. Verhandlungen der Anatomischen Gesellschaft, 71, 1385-1388.

Shibata S (1959) On the facial musculature of Macacus cyclopsis. Okajimas Folia Anatomica Japonica, 34, 159-176.

Sullivan S, McGechie F, Middleton K, Holliday C (2019) 3D Muscle Architecture of the Pectoral Muscles of European Starling (Sturnus vulgaris). Integrative Organismal Biology, 1, oby010. 
295 Sullivan WE, Osgood CW (1925) The facialis musculature of the orang, Simia satyrus. The Anatomical Record, 29, 195-243.

297 298

Swindler DR, Wood CD (1973) An Atlas of Primate Gross Anatomy: Baboon, Chimpanzee, and Man.

Watanabe, K., Facial muscles and muscles of mastication, in Bergman's Comprehensive Encyclopedia of Human Anatomic Variation. Tubbs RS, Shoja MM, Loukas M (Eds.). 2016, Wiley: Hoboken, NJ.

\section{Figure Legends}

Figure 1. 2D coronal slice from the contrast-enhanced image stack of the facemask of Eulemur flavifrons, with visible mimetic muscles segmented. Muscle abbreviations as follows: F: frontalis, OCC: occipitalis, SAL: superior auriculolabialis, OOR: orbicularis oris, P: platysma. Orientation abbreviations as follows: Spr: superior, Sfl: superficial, Inf: inferior.

Figure 2. A: Digital rendering of the mimetic muscles of Eulemur flavifrons, derived from a contrastenhanced face mask. Muscle abbreviations as follows: F: frontalis, OCC: occipitalis, OOC: orbicularis oculi, SAL: superior auriculolabialis, IAL: inferior auriculolabialis, AA: anterior auricularis, $\mathrm{PA}(\mathrm{S})$ : posterior auricularis (superior), $\mathrm{PA}(\mathrm{I})$ : posterior auricularis (inferior), $\mathrm{DH}$ : depressor helicis, MA: mandibuloauricularis, TR: tragicus, LL: levator labii, OOR: orbicularis oris, M: mentalis, P: platysma. Pink shading $\left(^{*}\right)$ indicates the aponeurotic sheet that connects the frontalis and occipitalis portions of the combined occipito-frontalis complex; as this aponeurotic sheet is non-muscular, it was not stained and not segmented. B: superimposition of the mimetic musculature of Eulemur flavifrons onto a volume rendering of the bony facial skeleton. 


\section{Table $\mathbf{1}$ (on next page)}

Volumetric measurements of key muscles of facial expression within Eulemur flavifrons. 
1 Table 1. Volumetric measurements of key muscles of facial expression within Eulemur

2 flavifrons.

\begin{tabular}{|c|c|c|c|c|}
\hline Muscle Region & Muscle & $\begin{array}{l}\text { Inferred Muscle Function in } \\
\text { E. flavifrons }\end{array}$ & $\begin{array}{l}\text { Volume } \\
\left(\mathrm{mm}^{3}\right)\end{array}$ & $\begin{array}{c}\text { Proportion of Total } \\
\text { Mimetic Musculature (\%) }\end{array}$ \\
\hline \multirow{3}{*}{$\begin{array}{l}\text { Muscles of the } \\
\text { Superciliary/Orbital } \\
\text { Region }\end{array}$} & Frontalis & Elevation of the brow & 68.86 & $6.4 \%$ \\
\hline & Occipitalis & Posterior movement of the scalp & 39.87 & $3.7 \%$ \\
\hline & Orbicularis Oculi & Closure of the eye & 329.96 & $30.4 \%$ \\
\hline \multirow{7}{*}{$\begin{array}{l}\text { Muscles of the } \\
\text { Midface/Mouth } \\
\text { Region }\end{array}$} & Orbicularis Oris & Pursing of the lips & 459.34 & $42.4 \%$ \\
\hline & Superior & Elevation of the corner of the mouth & 69.53 & $6.0 \%$ \\
\hline & Auriculolabialis & & & \\
\hline & Inferior & Retraction of the corner of the mouth & 59.94 & $5.9 \%$ \\
\hline & Auriculolabialis & & & \\
\hline & Mentalis & Protrusion of the lower lip & 9.65 & $0.9 \%$ \\
\hline & Levator Labii & Elevation of the upper lip & 7.03 & $0.6 \%$ \\
\hline \multirow{7}{*}{$\begin{array}{l}\text { Muscles } \\
\text { Surrounding the } \\
\text { external ear }\end{array}$} & Anterior Auricularis & Elevation of the ear & 3.66 & $0.3 \%$ \\
\hline & Superior Posterior & Flattening/retraction of the ear & 14.96 & $1.4 \%$ \\
\hline & Auricularis & & & \\
\hline & Inferior Posterior & Flattening/retraction of the ear & 8.17 & $0.8 \%$ \\
\hline & Tragicus & Retracts/opens the ear & 5.48 & $0.5 \%$ \\
\hline & Depressor Helicis & Anterior flattening of the ear & 6.18 & $0.6 \%$ \\
\hline & Mandibuloauricularis & Anterior flattening of the ear & 5.46 & $0.5 \%$ \\
\hline
\end{tabular}

3 


\section{Table 2 (on next page)}

Description of the arrangement of mimetic muscles analyzed in $E$. flavifrons relative to previous studies of the facial muscles in Lemuroidea and select other primate taxa. 
1 Table 2. Description of the arrangement of mimetic muscles analyzed in E. flavifrons relative to 2 previous studies of the facial muscles in Lemuroidea and select other primate taxa.

\begin{tabular}{|c|c|c|}
\hline Muscle & Previous Descriptions & $\begin{array}{l}\text { Arrangement within } \\
\text { Eulemur flavifrons }\end{array}$ \\
\hline Frontalis & $\begin{array}{l}\text { In Lemur catta, this muscle covers both sides of the skull with the } \\
\text { fibers being more developed posteriorly (Murie and Mivart, 1869). } \\
\text { In Eulemur macaco, the frontalis is relatively small but interlaces } \\
\text { with the orbicularis oculi, with fibers ending into the skin of the } \\
\text { eyebrow (Lightoller, 1934); in Otolemur this muscle is large, } \\
\text { attaching to the scalp }\end{array}$ & $\begin{array}{l}\text { This muscle accords with } \\
\text { previous descriptions. }\end{array}$ \\
\hline Occipitalis & $\begin{array}{l}\text { In Otolemur, this muscle is described as travelling to the level of the } \\
\text { superior concha, giving rise to the anterior auricularis/atollens } \\
\text { aurem (Burrows et al., 2003). In Lemur catta, the muscle is broad } \\
\text { with strongly developed fibers in its posterior portion, while in } \\
\text { Galago crassicaudatus it is thin, though retains well-developed } \\
\text { fibers (Murie and Mivart, 1869). }\end{array}$ & $\begin{array}{l}\text { This muscle accords with } \\
\text { previous descriptions. }\end{array}$ \\
\hline $\begin{array}{l}\text { Orbicularis } \\
\text { oculi }\end{array}$ & $\begin{array}{l}\text { In all previous descriptions, this muscle is formed by a thin sheet of } \\
\text { circular fibres surrounding the rima palpebrarum. In a hybrid lemur } \\
\text { described by Lightoller (1934), several fine fibers continue } \\
\text { anteriorly towards the nose. In Otolemur, its superior extent is } \\
\text { limited to the superciliary region, but inferiorly the muscle extends } \\
\text { almost to the region of the upper lip, where it gives rise to the } \\
\text { superior auriculolabialis muscle (Burrows 2003). }\end{array}$ & $\begin{array}{l}\text { This muscle largely accords with } \\
\text { previous descriptions, but did not } \\
\text { give rise to the superior } \\
\text { auriculolabialis as was described } \\
\text { in Otolemur. }\end{array}$ \\
\hline $\begin{array}{l}\text { Orbicularis } \\
\text { oris }\end{array}$ & $\begin{array}{l}\text { In Lemur catta the orbicularis oris is described as elongated and } \\
\text { narrow (Murie and Mivart, 1869). Across Lemuroidea, the muscle } \\
\text { is described as a primitive ring of muscle by Huber (1930) and as a } \\
\text { thickened ribbon around the lips, coupled with a flat, sheet, like } \\
\text { body which extends outwards by Lightoller (1934). In Otolemur, } \\
\text { the muscle is described as dense and sphincter-like, being } \\
\text { occasionally integrated with the inferior extent of the levator labii } \\
\text { (Burrows and Smith, 2003). }\end{array}$ & $\begin{array}{l}\text { This muscle accords with } \\
\text { previous descriptions. }\end{array}$ \\
\hline $\begin{array}{c}\text { Superior } \\
\text { Auriculo- } \\
\text { labialis }\end{array}$ & $\begin{array}{l}\text { Within Lemuroidea this muscle is described as being tightly } \\
\text { integrated with the inferior auriculolabialis, with fibers from both } \\
\text { muscles running from the ear towards the upper lip (Lightoller } \\
\text { 1934). Significant differentiation between superior and inferior } \\
\text { muscles are reported, however, within Otolemur by Burrows and } \\
\text { Smith (2003). }\end{array}$ & $\begin{array}{l}\text { The superior auriculolabialis in } \\
\text { E. flavifrons largely resembles } \\
\text { the description of this muscle in } \\
\text { L. niger (now E. macoco). It did } \\
\text { not arise from the orbicularis } \\
\text { oculi as described in Otolemur. }\end{array}$ \\
\hline $\begin{array}{l}\text { Inferior } \\
\text { Auriculo- } \\
\text { labialis }\end{array}$ & $\begin{array}{l}\text { Huber (1930) notes in both Lemuroidea and Tarsius a broad } \\
\text { connection of the inferior portion of the auriculolabialis with the } \\
\text { platysma. This same association is noted by Burrows and Smith } \\
\text { (2003) in Otolemur, who observe strong integration with the } \\
\text { platysma, with inferior fibers arising from the superior border of the } \\
\text { platysma muscle at about one-third of its length; and in Lemur catta } \\
\text { by Lightoller (1934), who describe this muscle as following the } \\
\text { same plane as the platysma, with the two muscles sharing closely } \\
\text { united fibers. }\end{array}$ & $\begin{array}{l}\text { The inferior auriculolabialis in } E \text {. } \\
\text { flavifrons closely resembles } \\
\text { previous descriptions of this } \\
\text { muscle across several species } \\
\text { within Lemuroidea and } \\
\text { Lorisoidea. }\end{array}$ \\
\hline
\end{tabular}




\begin{tabular}{|c|c|c|}
\hline Mentalis & $\begin{array}{l}\text { In Lemuroidea, the muscle is reported to vary in size from very } \\
\text { small with a few oblique fibers (Burrows and Smith, 2003) to large } \\
\text { and fan-shaped (Lightoll,er 1934). It originates muscularly from } \\
\text { fibers of the orbicularis oris and runs to the alveolar margin of the } \\
\text { mandible. }\end{array}$ & $\begin{array}{l}\text { The inferior auriculolabialis in } E \text {. } \\
\text { flavifrons closely resembles } \\
\text { previous descriptions of this } \\
\text { muscle, but shares closer } \\
\text { associated with the platysma than } \\
\text { described in previous accounts. }\end{array}$ \\
\hline $\begin{array}{l}\text { Levator } \\
\text { Labii }\end{array}$ & $\begin{array}{l}\text { Described in Otolemur as a single band in } 2 / 3 \text { rds of specimens and } \\
\text { as two-pronged in } 1 / 3^{\text {rd }} \text { of specimens (Burrows and Smith, 2003). } \\
\text { Five of the six two-pronged cases were observed in one taxon }(O \text {. } \\
\text { crassicaudatus). It passes from the skin of the rostrum/midface to } \\
\text { insert into skin superior to the upper lip. }\end{array}$ & $\begin{array}{l}\text { This muscle appears to be single- } \\
\text { bellied, as in the case of } 2 / 3 \text { rds of } \\
\text { specimens of Otolemur, ad } \\
\text { otherwise accords with previous } \\
\text { descriptions. }\end{array}$ \\
\hline Platysma & $\begin{array}{l}\text { In Otolemur, the platysma is described as a broad, flat muscle with } \\
\text { horizontal fibers that extends from the commissure of the mouth to } \\
\text { the region posterior to the ear. Superiorly, it gives rise to the inferior } \\
\text { auriculolabialis muscle (Burrows and Smith, 2003). The muscle is } \\
\text { similarly described in Lemur catta by Lightoller (1934). }\end{array}$ & $\begin{array}{l}\text { The inferior auriculolabialis in } E \text {. } \\
\text { flavifrons closely resembles } \\
\text { previous descriptions. }\end{array}$ \\
\hline $\begin{array}{l}\text { Anterior } \\
\text { Auricularis }\end{array}$ & $\begin{array}{l}\text { The anterior auricularis exists as a number of parallel bands running } \\
\text { from the concha within Lemuroidea (Ruge, 1885); No true M. } \\
\text { auricularis anterior is identified within Lemur niger (now E. } \\
\text { macaco), rather there is a large and powerful M. orbito-auricularis } \\
\text { (Lightoller, 1934); In G. gorilla, the anterior auricularis is attached } \\
\text { by a tendinous plate to the frontalis (Huber, 1930); In Macaca } \\
\text { mulatta, an anterior auricularis is imperfectly separated from the } \\
\text { frontalis, inserting into fascia near the superoanterior portion of } \\
\text { cartilaginous pinna (Burrows et al., 2009). }\end{array}$ & $\begin{array}{l}\text { The arrangement of this muscle } \\
\text { in E. flavifrons most closely } \\
\text { accords to the description by } \\
\text { Burrows (2009) in } M \text {. mulatta, } \\
\text { being partially associated with } \\
\text { the posterior border of the } \\
\text { frontalis and lying towards the } \\
\text { superoanterior border of the ear. }\end{array}$ \\
\hline $\begin{array}{l}\text { Posterior } \\
\text { Auricularis }\end{array}$ & $\begin{array}{l}\text { In Lemuroidea, the M. auricularis posterior consists of three } \\
\text { muscular bands, two inserting into the posterior surface of the } \\
\text { auricular cartilage and the third into the lower pole of the concha } \\
\text { (Lightoller, 1934); In M. mulatta, this muscle consists of two slips } \\
\text { of relatively equal size that attach into fascia near posterior region } \\
\text { of the cartilage of the pinna (Burrows et al., 2009) }\end{array}$ & $\begin{array}{l}\text { In E. flavifrons, this muscle } \\
\text { consists of two bellies as } \\
\text { described by Burrows (2009); } \\
\text { however, these were not of equal } \\
\text { size. Rather, the superior belly } \\
\text { possesses a volume almost twice } \\
\text { as large as the inferior. }\end{array}$ \\
\hline Tragicus & $\begin{array}{l}\text { Limited descriptions exist for this muscle within primates; in } M \text {. } \\
m u l a t t a, \text { it is described as a small muscle consisting of arcing fibers } \\
\text { that run from the anterior edge of the helix of the pinna to the tragus } \\
\text { (Burrows et al., 2009). }\end{array}$ & $\begin{array}{l}\text { The arrangement of this muscle } \\
\text { in E. flavifrons most closely } \\
\text { accords to the description by } \\
\text { Burrows (2009) in M. mulatta. }\end{array}$ \\
\hline $\begin{array}{l}\text { Depressor } \\
\text { Helicis }\end{array}$ & $\begin{array}{l}\text { Attaches to the tragus and the anteroinferior concha in Otolemur } \\
\text { (Burrows and Smith, 2003) and is similarly described within the } \\
\text { genus Lemur by Ruge (1885). However, Burrows and Smith (2003) } \\
\text { note that this muscle was absent in 35\% of Otolemur specimens. }\end{array}$ & $\begin{array}{l}\text { This muscle accords with } \\
\text { previous descriptions. }\end{array}$ \\
\hline $\begin{array}{l}\text { Mandibulo- } \\
\text { auricularis }\end{array}$ & $\begin{array}{l}\text { In Otolemur, this muscle consists of a short, wide set of vertically- } \\
\text { oriented fibers, sitting immediately anterior to the depressor helicis. } \\
\text { The muscle is similarly positioned across Lemuroidea (Lightoller, } \\
\text { 1934). }\end{array}$ & $\begin{array}{l}\text { This muscle accords with } \\
\text { previous descriptions. }\end{array}$ \\
\hline
\end{tabular}


Figure 1

2D slice from the contrast-enhanced image stack of the facemask of Eulemur flavifrons, with visible mimetic muscles segmented.

Muscle abbreviations as follows: F: frontalis, OCC: occipitalis, SAL: superior auriculolabialis, OOR: orbicularis oris, P: platysma. 


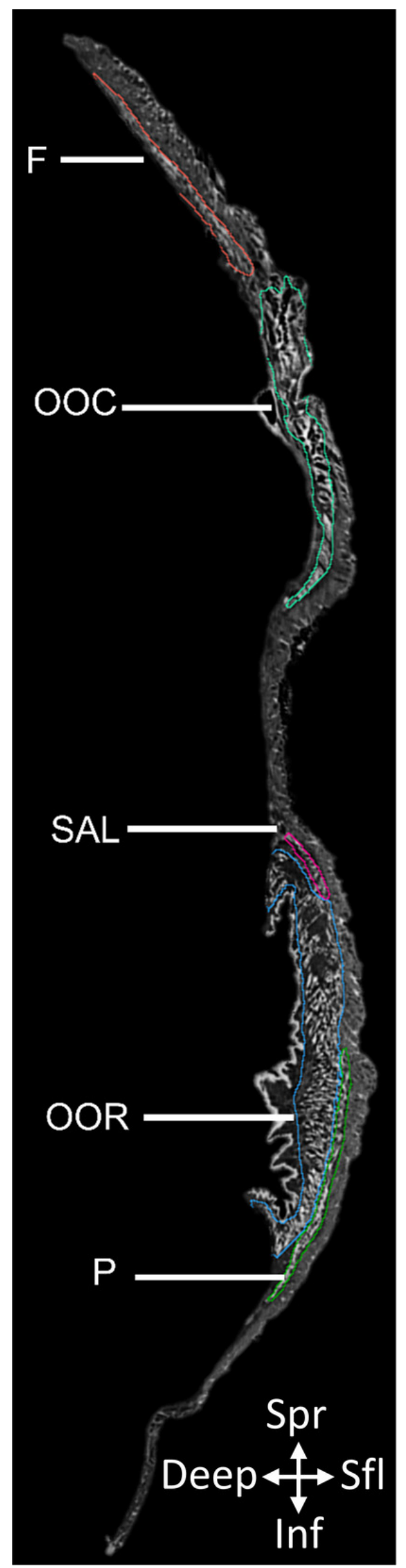

PeerJ reviewing PDF | (2019:12:44023:2:0:NEW 7 May 2020) 


\section{Figure 2}

Above: Digital rendering of the mimetic muscles of Eulemur flavifrons, derived from a contrast-enhanced face mask. Below: superimposition of the mimetic muscles onto the bony facial skeleton.

Muscle abbreviations as follows: F: frontalis, OCC: occipitalis, OOC: orbicularis oculi, SAL: superior auriculolabialis, IAL: inferior auriculolabialis, AA: anterior auricularis, PA(S): posterior auricularis (superior), $\mathrm{PA}(\mathrm{I})$ : posterior auricularis (inferior), $\mathrm{DH}$ : depressor helicis, MA: mandibuloauricularis, TR: tragicus, LL: levator labii, OOR: orbicularis oris, M: mentalis, P: platysma. Pink shading $(*)$ indicates the aponeurotic sheet that connects the frontalis and occipitalis portions of the combined occipito-frontalis complex; as this aponeurotic sheet is non-muscular, it was not stained and not segmented. 


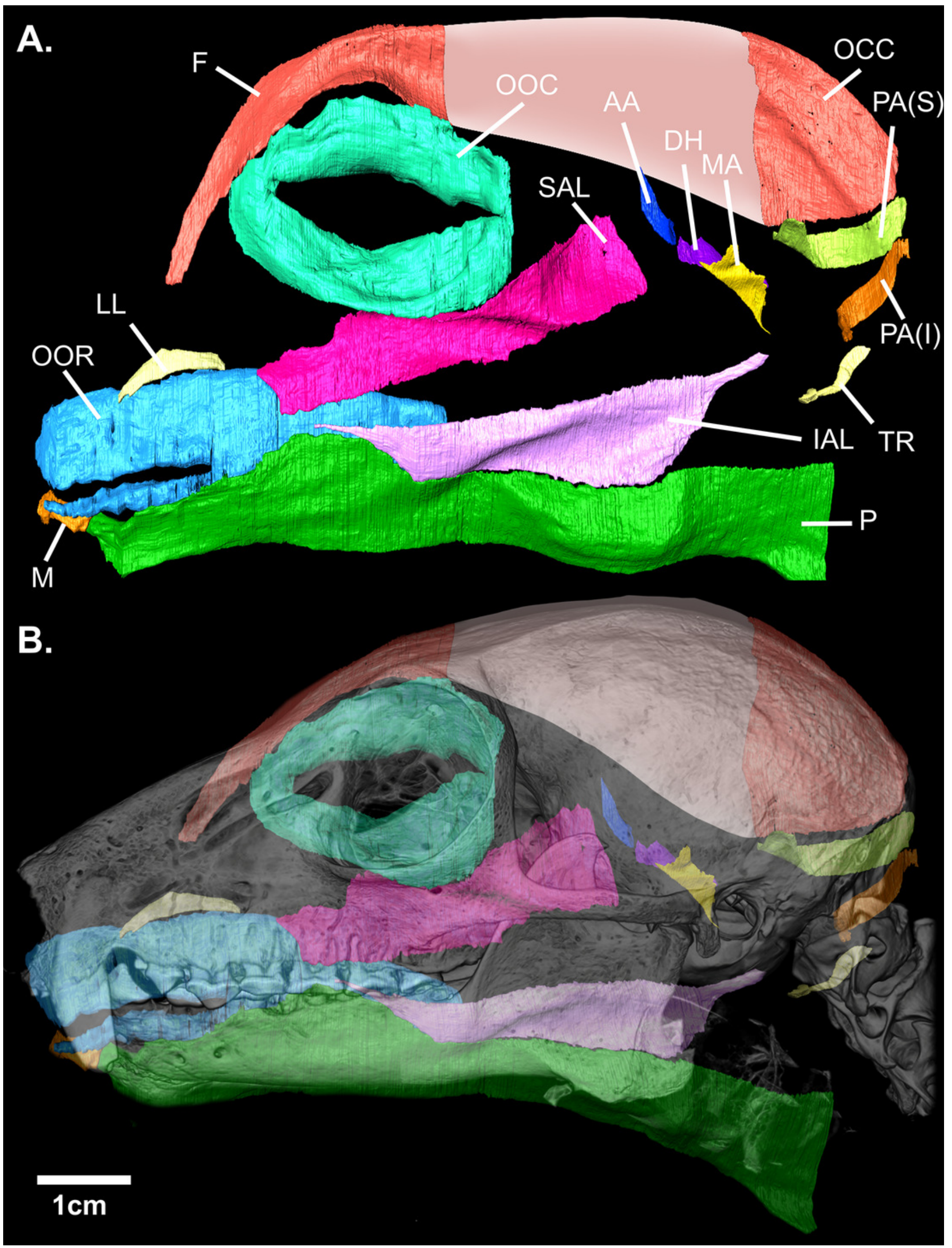

